\title{
THE ANNIVERSARY GATHERING AT B. F. ALLEN'S
}

The following reprints were taken from the Daily State Register, Des Moines, Iowa. The articles were originally compiled by the Department of Adult Education, Des Moines Public School System, for a "Highlights of Iowa History Class," 1961.

Saturday, January 30,1869

Last evening the new and magnificent residence of B. F. Allen, Esq. was thrown open to the friends of himself and wife, it being the fifteenth anniversary of their wedding day. Though the weather was stormy and exceedingly forbidding, the large and commodious edifice was thronged with the numerous friends of the host and hostess, some of whom came from Chicago and St. Louis. But we will leave a description of these now, and look through the rooms for the benefit of those who are not present. A description of the magnificance of the house in its internal arrangements would require more space than we have now to give.

Entering the main hall on the north side you pass into the corridor or main hall. This is wide and spacious, and is fifteen feet in height. About midway of the building it is intersected with a hall extending to the south wing of the house. The floor of the hall is of white and black walnut over which is spread a Wilton carpet. On the right of the hall stands a wardrobe stand of walnut, with Lisbon marble pier stand, over which is a mirror 9 by 6 feet. It is furnished with gilt pins.

At the intersection of the south hall, on either side, stand two magnificent alabaster vases, richly carved and five feet high.

At the right as you enter the hall, is the entrance to the Drawing Room, in which is displayed the greatest magnificence of upholsters art seen in this country. The furniture is made in the ancient Grecian style, and consists of two sofas, two arm chairs, four sitting chairs, two reception chairs, 2 drab and crimson crinoline chairs, 2 French bebe chairs, 1 center table, 2 pedestals, surmounted with bronze statues, 2 elegant flower stands, 1 cabinet, inlaid with various kinds of wood in mosaic, which cost $\$ 800$. Here is also a mantle mirror on one side, finished in rose wood, gilt and glass. The curtains are of the heaviest crimson satin. The carpets made to fit the room are of the Exminister make.

The center table above mentioned is a rare piece of workmanship being elaborately ornamented, top and sides, with various woods in mosaic. On the stretcher is carved images. The cost of this table was $\$ 1,000$, and is said to be the richest piece of work of its kind in this country. It is not large but costly.

Adjoining the drawing-room on the south is the music room, in which stands a seventeen-hundred dollar Chickering, Louis XIVth Grand Square Piano. The furniture in this room is finished with drab and crimson satin; curtains of the same.

At the left of the hall we enter the library room which is furnished with exquisite taste and according to the "fitness of things." The library vases are of French Walnut, plate glass doors surmounted with bronze statues. The furniture consists of 4 arm chairs, 2 arm chairs upholstered 
with crimson, black and green tapestry; a library table. On the east side is a mirror $9 \mathrm{ft}$. $6 \times 6 \mathrm{ft}$. 2 . Corresponding with and opposite the one on the west side of the drawing room, which gives to one standing between a scene of magnificent distance. The windows are furnished with Grecian cornices and lambrekens in crimson black and green tapestry. The carpet in this room is Wilton, and in one piece.

Passing to the south, we enter the Sitting Room on the left, where is a statuary marble mantle surmounted with another mirror $9 \times 6 \mathrm{ft}$. In this room the cornices and finish is of gilt. The tapestry being green, crimson and gold. Here are 2 bebe arm chairs, 2 crepo chairs, 1 crepo rocker, 1 ebony center table with Lisbon marble top, 1 walnut and gilt oriental chair, 2 rose wood and gilt pedestals surmounted with bronze statuetts.

Opposite this room is the Dining Room in which is a French walnut Side Board, richly ornamented with carved sea-horses and Grecian heads, and topped with Lisbon marble; an iron silverware safe, richly ornamented; an extension table 18 feet long; chairs in an ancient Grecian style, and a dumb waiter. The cost of the Side Board was $\$ 900$. In this room is also a Lisbon Marble mantel and mirror $9 \times 6$.

Passing up the broad stairs at the south end of the hall, over which in large figures, formed of evergreens and leaves of house-plants is "1854-1869," we reach the north east room.-Here is a bedstead, bureau and mirror; a statuary marble mantel, 1 commode, 1 fancy table inlaid with various woods, 1 lounge, 4 chairs, 1 rocker, 1 French secretary. The furniture in this room is of French walnut, ebony and gilt. The upholstery of rich tapestry, drab ground, with gold stripe and flowers. -The cornices are walnut finished with drapery.

The north-east room is furnished with French walnut and ebony carved bedstead, bureau, 1 commode, round table, 4 chairs, and sofa. The upholstery is of crimson brocatelle; the curtains of same, hung in Grecian cornices.

Over the Hall is a boudoir furnished with drab, blue and gold drapery, gilt cornices, Turkish chairs, tables, and 4 imported Venetian chairs.

The south-east room is the family room, and here has been displayed the utmost taste. There is a bedstead, dressing case, commode dressing case, Turkish chair, reading chair with desk attachment, two Vienna rocking chairs, work table and oval table. The upholstery in this room is of leather colored, ponche green, black and gold tapestry. Attached to this room is a nursery room, bath room, etc., and bell calls connecting with all parts of the house.

The furniture was made by J. Ziegler \& Co., New York, expressly for this house, the moulds and designs having been made by the makers, and fitted to its place by Mr. H. C. Glinsmann, of the firm, who is now here for that purpose. The carpets and curtains were from A. T. Stewarts, on Broadway, New York. It is doubtful whether over the ocean could be produced more elegant goods or of better designs.

The hour of ten o'clock having arrived, supper is announced, and the vast throng is ordered to refreshments, which were prepared by Mr. John Wright of the Opera House Restaurant, Chicago.

Scattered ${ }^{\bullet}$ all over the house were flowers in bloom, which hightened the charm of the occasion. Wearied with gazing on the luxuriance 
of the place, and the festivities of the occasion, at the "we sma hours ayant the twa!" the guests departed, with blessings on the heads of the host and hostess, and thus closed the most rechere gathering, in the most elegant mansion, which has taken place west of the Hudson.

\section{DAILY STATE REGISTER, Des Moines, lowa, Sunday, January 31, 1869 FURTHER NOTES OF THE WEDDING ANNIVERSARY OF B. F. ALLEN AND WIFE}

In our yesterday's issue, owing to the late hours and bad weather which delayed our reporter past the time of going to press, we were unable to speak of the anniversary gathering at the mansion of $B, F$. Allen at the length and minuteness its general excellencies deserved. Such a brilliant affair, undoubtedly and confessedly the finest ever given at a private residence, in the Northwest, occurring in a city not yet out of its teens and which is yet called a town of the frontier, is not merely a matter of pride to the estimable persons, giving it, but also a proud honor for the ambitious young city in which it was given. Larger and older cities parade smaller matters as evidence of their advanced civilization and aristocratic preeminence. If such evidences are causes for self-gratulation with metropolitan cities, how much more so are they in this city whose ground is scarcely yet free from the moccasin tracks of the savage, and which is not yet recognized by the Eastern people as a town to be known among cities? The founders and first settlers of Des Moines are still here, still young, and are still the sturdy, prominent business men of the place. The work around them is not the work of their fathers; their own arms hewed out of the forests, laid the foundation stones, and built the city, and the day of its greatness in its coming finds these pioneers and builders not yet the meridian of life.

Among those who have grown up with the city and aided its growing, no one is so conspicuous as Mr. Allen, who, with his good wife, celebrated the fifteenth anniversary of his marriage on Friday evening. Eighteen years ago, Mr. Allen came to Des Moines a young man, with moderate means. With others he entered the wildernss with his fortune to win. As public spirited as he is energetic, his whole course upward has been marked with countless evidence that his ambition has been as great to build up Des Moines as it was to raise himself. The good he has worked for the city is beyond estimation. His way to wealth has been one of honor and uprightness; and the best endorsement the man has today is, that cordial confidence and good will which is extended to him by those who begun business with him and have been his business associates up to the present time.

Among the party which thronged his mansion on Friday evening the most delighted of all were his neighbors in the days when the aristocracy of the city lived in $\log$ houses and called a candy pulling an affair so elegant as not to be sneezed at. While all others enjoyed the social pleasures and bounteous hospitalities of the evening, these old settlers appreciated it with a zest and pride no others could feel. For them to realize that their Des Moines was graced with the most magnificent private residence, and the most luxuriantly equipped, west of the faroff Hudson river, was not possible without bewilderment. For a young town, away out here on the prairie sea, to eclipse good old Cincinnati, ambitious Chicago, and aristocratic St. Louis, is no light honor to bedeck 
the Capital City of Iowa with. Few men have two hundred and fifty thousand dollars to spend in fitting up themselves a home, and Des Moines is the only city in the west which has a gentleman who has done it.

Having become fairly established in their new horne, Mr. \& Mrs. Allen made the fifteenth anniversary of their marriage an occasion for inviting their friends to see them. -Over one thousand invitations were issued. - In addition to their Des Moines friends large parties were in attendance from Chicago and the river cities of our State. Among the notables from Chicago were Messrs. L. L. Coburn, R. A. Ketchum, W. F. Brackett, J. B. Raymond, W. B. Walker, James Wood, Chas. J. Connell, who were accompanied by Miss Cobb, Miss Matteson, Miss Rosencrans, Miss Rice, Miss Doty, and Mrs. Cobb. W. W. Boyington, the celebrated architect, with his wife and son, were also of the Chicago party. The Chicago press was represented by Fred F. Cook, of the Tribune; Wm. A. Campbell, of the Republican; and J. W. Knowlton, of the Times. Judge Finch, of the Indianapolis Mirror, and his wife embraced the opportunity of visiting $\mathrm{Mr}$. Allen, who is a nephew of the Judge. Of the distinguished men of our own State were Governor Merrill, General Wright, Secretary of State; John A. Elliott, Auditor of State; and Major Rankin, Treasurer of State. Several of the Judges of the Supreme Court were also in attendance, -also Hon. F. W. Palmer, Congressman-elect from this District, and Hon. John A. Kasson, exmember of Congress. Among the military men were Adjutant General Baker and General G. W. Clark. Many other distinguished persons were present, but the roll would run too long if we followed all.

The large company, which in the largest of residences would have been packed and crowded beyond comfort's point, in the large and roomy apartments of this palace home found no discomfort. There was room in abundance, and the ladies could promenade free from fear of the blundering footfalls of awkward men (like me) disturbing their sweeping trains. The intelligent bearing of the company was not more marked and conspicuous than their dress was fashionable and elegant. The gentlemen will not expect us to speak of them to any extent of minuteness or praise in this matter, although they were arrayed in apparel in every way complimentary to their taste. The toilettes of the ladies far exceeded all expectation. In richness, elegance, and exquisiteness of attire, they excited universal admiration. In tastefulness of dress, grace of manner, intelligence of bearing, culture of mind, and beauty of person, the ladies of our young city are celebrated, and on this gala night they were brighter and sweeter than ever. The drawing rooms of gorgeous New York, elegant Boston, or stately Philadelphia are never graced with more brilliant appearing ladies than the charming ones that thronged these parlors on Friday evening. We regret that we have not a Jenkinsistic fountain in our pencil so that we could describe the exquisite toilettes of particular ladies, but as scores and scores were dressed with equal taste and richness the task would be endless. We can only say that we felt prond of them-a pride which was increased by the cordial and flattering compliments bestowed by the visitors from abroad who had come here with no expectation of seeing a frontier town fully up to the imperious requirements of the empress of fashion.

The evening was passed in an abondon of intelligent pleasure. The 
spacious apartments, the graceful, cordial hospitality of host and hostess, and the free and unrestrained commingling of the guests, made all feel delightfully at home and at ease. The night outside was bad and boisterous, but within all was merry and bright, and all seemed seized with the determination to enjoy an evening of genuine, spontaneous pleasure, a captivity of enchantment to which the mobile nature of American society seldom yields.

Our article of yesterday described the preparations made for the entertainment of the guests. On every side were bright flowers which were very grateful to eyes which have looked upon snow and winter waste for several months. Some idea of the profusion with which they were strewn may be gained by the statement that two thousand dollars' worth were used in the decorations-the one bouquet gracing the center of the supper table alone costing seven hundred dollars. The supper itself was of royal elegance. Such a bounteous banquet board is rarely spread-some six thousand dollars being expended in its supply.

Midnight came and passed away, finding the party but fairly begun in their pleasure. The grand piano, first under the masterly teacher, Will Lehman, and afterwards under the almost perfect hands of Prof. Apel, gave out entrancing music, flooding the whole house with sweet melody. Miss Kittie Allen, Miss Mate Newton, and Maj. Studer, each favored the company with a superbly rendered solo, and Messrs. Hatton and Sherman sang one of their splendid duets.

The rapid flight of time soon brought the hears of early morn, when the guests with many cordial good byes to the manly host, and amiable hostess, - who had done everything that could be done to make the evening one of rare pleasure-took their departure, happy and grateful that they had been of those who had taken part in the festivities of a wedding anniversary which had found the celebrating couple so highly blessed and so willing to bless others.

Although this was properly a chrystal wedding, it was so announced that presents were not expected. Mrs. J. C. Savery, however, took the privilege of presenting a beautiful and complete set of glass table-ware, the main piece of which bore the eloquent aspiration: "Dieu vous garde"-"God keep you"-These words so happily chosen charmingly mirror the wish of ever person attending the anniversary. 
Copyright of Annals of Iowa is the property of State of Iowa, by \& through the State Historical Society of Iowa and its content may not be copied or emailed to multiple sites or posted to a listserv without the copyright holder's express written permission. However, users may print, download, or email articles for individual use. 